\title{
ANALISIS STRATEGI PRODUK DALAM UPAYA MENINGKATKAN PENJUALAN PT. HTI BUMI PERSADA BANYUASIN
}

\author{
Totok Sudiyanto *) \\ Rismansyah *)
}

\begin{abstract}
ABSTRAK
Penelitian ini bertujuan untuk mengetahui dan menganalisis startegi produk dalam upaya meningkatkan penjualan pada PT. HTI Bumi Persada Banyuasin. Rumusan masalah dalam penelitian ini adalah bagaimana analisis strategi produk dalam upaya meningkatkan penjualan PT. HTI Bumi Persada Banyuasin. Tujuan penelitian ini adalah untuk mengetahui dan menganalisa startegi produk dalam upaya meningkatkan penjualan PT. HTI Bumi Persada Banyuasin. Jenis penelitian yang di gunakan yaitu analisis deskriptif kualitatif. Tehnik pengumpulan data yang digunakan adalah dengan observasi dan wawancara.

Hasil penelitian di PT. HTI Bumi Persada Banyuasin adalah menggunakan strategi bauran produk, strategi penggunaan merek dagang, strategi tenaga penjualan ( sales ) serta strategi pemilihan media masa. Untuk itu penulis menarik kesimpulan dan mencoba memberi saran-saran yang mungkin dapat berguna sebagai bahan pertimbaNgan bagi PT. HTI Bumi Persada Banyuasin yaitu mencoba memperbesar sarana dan menunjang produk yang ditawarkan kepada konsumen agar bisa lebih meningkatkan lagi penjualan produk yang ditawarkan.
\end{abstract}

Kata Kunci : Segmen Pasar, Hirarki Produk, Siklus Kehidupan Produk dan Merek.

\section{A. Latar Belakang}

Pemasaran merupakan salah satu kegiatan yang dilakukan oleh perusahaan yang bertujuan untuk menyediakan produk yang berkualitas tinggi sehingga dipakai oleh konsumen secara terus menerus. Dalam usaha untuk mencapai tujuannya setiap perusahaan akan memenuhi berbagai masalah, oleh karena itu sebuah perusahaan akan memenuhi berbagai masalah, dan perusahaan harus bisa memperhatikan produk- produk yang mereka hasilkan dan terus meningkatkan kualitas atribut produk berupa desain produk yang digunakan dan dapat secara terus menerus mereka gunakan sehingga konsumen memutuskan untuk membeli produk tersebut.
Pemasaran tidak hanya dari satu sudut pandang saja, pemasaran terdiri dari satu pengambilan keputusan, manajemen sebelum produk tersebut direncanakan dan akan terus terlibat sampai produk terjual. Sehingga dapat digunakan dan di konsumsi sehingga produk tersebut menjadi salah satu kebutuhan yang harus dipenuhi oleh konsumen dan si pemakai.

Di dalam sebuah perusahaan untuk menghadapi persaingan dan mempertahankan kelangsungan hidup perusahaan, strategi pemasaran sangat diperlukan agar perusahaan dapat tetap hidup, berkembang dan mampu bersaing tidak hanya ditentukan perusahaan untuk meningkatkan kapasitas produksi tetapi juga dipengaruhi oleh perusahaan untuk menghasilkan 
produk yang berkualitas, maka setiap perusahaan harus menerapkan strategi yaitu melalui strategi pemasaran. Di mana strategi pemasaran disini sangat mempengaruhi tingkat penjualan produk.

Peran produk sangat penting bagi perusahaan, dimana setiap saat selalu adanya perubahan yang cepat dalam selera konsumen dan persaingan yang semakin ketat, hal ini menyebabkan suatu perusahaan di tuntut untuk mampu bersaing dengan perusahaan lain dan senantiasa menciptakan produk sesuai dengan kebutuhan atau keinginan konsumen. Agar konsumen merasa puas dengan produk yang dipakai atau digunakan. Dan sudah tentu perusahaan akan mendapat keuntungan yang maksimal.

Perusahaan PT. HTI Bumi Persada Banyuasin merupakan salah satu perusahaan yang bergerak dibidang produk makanan atau Bakery. Produk makanan yang dihasilkan seperti roti tawar, roti beragam rasa coklat, roti sobek dan lain - lain. Jika dilihat dari jangkauan daerah perusahaan ini hanya meliputi kotakota tertentu saja yang ada di Banyuasin dan sekitarnya.

Di dalam menghasilkan produknya PT. HTI Bumi Persada Banyuasin menggunakan bahan baku seperti tepung terigu, gula pasir, coklat butir, lemak roti dan lain- lain. Perusahaan PT. HTI Bumi Persada Banyuasin belakangan ini mengalami penurunan dalam penjualan produknya karena kurangnya promosi dalam melakukan penggenalan produknya, yang menyebabkan pula konsumen merasa bosan, sehingga konsumen merasa kurang puas dan tidak ingin lagi menggunakan dan memakan produk makanan mereka lagi. Maka hal ini menyebabkan omzet perusahaan menurun.

Dengan mulai memperbaiki iklim dan minat masyarakat dalam bidang makanan atau Bakery mengakibatkan tingkat persaingan di dunia makanan semakin ketat. Strategi pemasaran merupakan salah satu senjata bagi perusahaan untuk menghadapi persaingan pasar. Pada dasarnya strategi pemasaran adalah mencari kecocokan antara kemampuan internal perusahaan dengan peluang eksternal yang ada dipasar. Mencari kecocokan ini merupakan tanggung jawab dari bagian pemasaran untuk menerapkan strategi pemasaran yang sesuai dengan produk yang dihasilkan dan sesuai dengan segmen pasar yang ingin dituju oleh produk yang diluncurkan.

Menggenali karakteristik pasar dan struktur pasar sangatlah menguntungkan bagi perusahaan untuk tetap dapat bersaing dan survive (kelangsungan hidup perusahaan). Kelemahan dan keunggulan perusahaan hendaknya dianalisis sehingga menjadi sebuah titik tolak yang kuat buat perusahaan dalam mengambil keputusan yang efektif dan efisien serta untuk memperkuat posisinya dari para pesaing yang ada.

Tujuan utama dari perusahaan ialah pencapaian profit ( laba ) dan hal ini dapat juga sebagai tolak ukur dalam sukses atau tidaknya sebuah perusahaan dalam pencapaian tujuannya. Selain itu efektifitas dan efisiensi dalam menjalankan operasional perusahaan juga 
memegang peranan penting. Efisiensi yang dimaksud adalah strategi pemasaran yan4g dilakukan dengan perhitungan dan pertimbangan yang tepat sehingga tidak ada pemborosan biaya baik itu dalam operasional maupun dalam biaya promosi maupun iklan dan efektifitas yang dimaksud ialah pemilihan strategi pemasaran yang tepat dan sesuai dengan pasar yang dilayani oleh perusahaan sehingga sasaran yang ditetapkan dapat tercapai.

PT. HTI Bumi Persada Banyuasin sebagai salah satu perusahaan yang bergerak dalam bidang makanan atau
Bakery yang harus menghadapi persaingan yang cukup ketat dengan perusahaan Bakery lainnya. Agar PT. HTI Bumi Persada Banyuasin dapat bertahan dan berkembang dengan baik maka PT. HTI Bumi Persada Banyuasin harus dapat menciptakan kemampuan bersaing baik dalam hal jenis produk, sehinga dapat menghasilkan produk yang mampu bersaing dan memenangkan persaingan.

Berikut ini penulis sajikan data volume penjualan pada PT. HTI Bumi Persada Banyuasin dari bulan Mei sampai November.

Tabel 1

Penjualan PT. HTI Bumi Persada Banyuasin.

\begin{tabular}{|c|c|}
\hline Bulan & Penjualan \\
\hline Mei & $\operatorname{Rp~313.740.000;~}$ \\
\hline Juni & $\operatorname{Rp~464.400.000;}$ \\
\hline Juli & $\operatorname{Rp~338.400.000;~}$ \\
\hline Agustus & $\operatorname{Rp~559.500.000;}$ \\
\hline November & $\operatorname{Rp~675.900.700;}$ \\
\hline
\end{tabular}

Sumber : PT. HTI Bumi Persada Banyuasin

Dari data tabel diatas dapat di ketahui bahwa hasil volume penjualan pada PT. HTI Bumi Persada Banyuasin pada bulan Mei dan Juni adanya peningkatan dalam volume penjualannya, sedangkan pada bulan Juli volume penjualan pada PT. HTI Bumi Persada Banyuasin mengalami penurunan. Hal ini terlihat jelas pada tabel volume panjualan diatas. Volume penjualan menurun di sebabkan karena adanya kelemahan suatu produk yang belum memenuhi standar yang ada, sehingga konsumen berpaling kepada produk lain.
Adapun kelemahan produk pada PT. HTI Bumi Persada Banyuasin yaitu masih terdapat resiko kontaminasi bahan baku pada saat proses produksi, dan memiliki masa kadaluarsa yang singkat sehingga pengembalian produk ( retur penjualan ) meningkat, serta sulit mendistribusikan produk untuk jangkauan daerah - daerah selain kota besar. Dan aktivitas distribusi memiliki intensitas tinggi dan berbiaya tinggi karena sifat produk yang harus sering di supply mengingat produk tidak tahan lama. 
Lalu dibanding dengan perusahaan lain yang memiliki hasil produksi yang hangat, dan memiliki masa kadaluarsa yang panjang dan aktivitas distribusi yang luas.

\section{B. Rumusan Masalah}

Berdasarkan latar belakang yang telah diuraikan di atas maka perumusan masalah dalam penelitian ini adalah : Bagaimana Analisis Strategi Produk Dalam Upaya Meningkatkan Penjualan PT. HTI Bumi Persada Banyuasin ?

\section{Metode Penelitian}

Metode yang di gunakan dalam penelitian ini adalah metode penelitian deskriptif kualitatif yaitu penelitian yang dilakukan untuk mengetahui nilai variabel mandiri, baik satu variabel atau lebih dengan membuat perbandingan atau menghubungkan dengan variabel lain. Dengan menggunakan data yang berbentuk kata, kalimat, skema dan gambar dengan analisis tidak menggunakan statistik.

(Sugiyono,2011:35)

\section{Populasi dan Sampel \\ 1) Populasi}

Menurut Ridwan dan Akdon ( 2006 : 3 ) menyatakan bahwa populasi adalah keseluruhan atau unit hasil pengukuran yang menjadi objek penelitian. Populasi dalam penelitian ini sebanyak 54 orang.

\section{2) Sampel}

Hasan ( $2010: 84$ ) mendefinisikan bahwa sampel adalah bagian dari populasi yang di ambil melalui cara-cara tertentu yang juga memiliki karakteristik tertentu, jelas lengkap yang dianggap dapat mewakili populasi. Berdasarkan pendapat diatas maka pada penelitian ini akan menggunakan data sampel artinya sebagai konsumen PT. HTI Bumi Persada Banyuasin.
Menurut Roscoe dan Sugiyono ( 2010 : 129 ) ukuran sampel yang layak dalam penelitian adalah antara 54 orang. Berdasarkan pendapat diatas maka sampel dalam penelitian ini sebanyak 54 orang responden.

Berdasarkan uraian diatas maka penulis melakukan penelitian dengan meneliti seluruh populasi berupa keseluruhan karyawan yang bekerja pada PT. HTI Bumi Persada Banyuasin yang berjumlah 54 orang.

\section{E. Teknik Pengumpulan Data}

1) Observasi

Observasi adalah tehnik pengumpulan data yang dilakukan dengan mengadakan pengamatan secara langsung kepada objek yang diteliti.

2) Wawancara

Wawancara merupakan metode yang di gunakan untuk memperoleh informasi secara langsung, mendalam, dengan cara melakukan tanya jawab kepada pimpinan dan karyawa yang bersangkutan.

\section{F. Teknik Analisis Data}

Tehnik analisis data yang digunakan dalam penelitian ini adalah deskriptif kualitatif yaitu analisis yang mengambarkan suatu keadaan tertentu tanpa di hubungkan dengan variabel lain. Analisis ini tidak menggunakan data statistik akan tetapi mengambarkan kata-kata untuk memperoleh kesimpulan. Dalam penelitian ini penulis menganalisis fenomena yang terjadi di perusahaan kemudian di analisis untuk mencari strategi jalan keluarnya yang berdasarkan teori-teori yang relevan. Data di peroleh dari berbagai sumber, dengan menggunakan tehnik pengumpulan data melalui wawancara 
dan observasi, dan dilakukan secara terus menerus sampai datanya jenuh.

\section{G. Hasil Penelitian}

Berdasarkan pengamatan / observasi dan wawancara yang dilakukan oleh peneliti, strategi produk yang dilakukan PT. HTI Bumi Persada Banyuasin sebagai berikut :

\section{Strategi Bauran Produk}

Strategi bauran produk berkaitan dengan konsep hidup produk yang berfungsi membantu dan menjelaskan mengapa strategi bauran produk sangat penting. Strategi bauran produk menetapkan tahap untuk memilih strategi untuk tiap komponen strategi penentuan posisi, merupakan tujuan utama dari program pemasaran. Strategi bauran produk disesuaikan dengan strategi distribusi, harga dan promosi.

PT. HTI Bumi Persada Banyuasin juga memperhatikan setiap produk yang ada dalam perusahaan akhirnya tidak akan terpakai lagi karena pangsa pasar dan penjualan di kurangi produk saingan lalu keuntungan pada umunya akan menurun karena usia produk semakin menua.dan jika produk-produk itu tidak diubah atau diperbaiki maka laba, pangsa pasar dan penjualan akan berkurang sehingga pada akhirnya, perusahaan itu akan bangkrut. Oleh karena itu diperlukan strategi bauran produkyang tepat untuk meningkatkan kembali tingkat penjualan sekaligus meningkatkan kembali laba perusahaan.

Dalam menentukan anggaran pengeluaran untuk produk $\mathrm{PT}$. HTI Bumi Persada Banyuasin menggunakan metode sesuai dengan kemampuan perusahaan, artinya PT. HTI Bumi Persada
Banyuasin menetapkan anggaran produk pada tingkat yang perusahaan perkirakan dapat ditanggung oleh perusahaan tersebut. Namun dengan pemanfaatan dana yang efektif dan efisien serta strategi yang tepat yang dilakukan dapat meningkatkian penjualan seperti yang diharapkan oleh perusahaan. Adapun strategi lain yang dilakukan oleh PT. HTI Bumi Persada Banyuasin yaitu :

a) Enterprise Strategy

Strategi ini berkaitan dengan respons masyarakat. Setiap organisasi mempunyai hubungan dengan masyarakat. Masyarakat adalah kelompok yang berada diluar organisasi yang tidak dapat dikontrol.

Produk yang digolongkan berdasarkan konsumen / masyarakat membeli barang secara umum. Produk yang dibeli oleh masyarakat untuk memenuhi kepentingan sendiri sesuai kebutuhan yang diharapkan oleh masyarakat/ konsumen.

Mengingat perusahaan sejenis sangat banyak, tentu saja persaingan dibisnis ini sangat ketet, sehingga PT. HTI Bumi Persada Banyuasin harus pandai-pandai memilih alat strategi yang tepat, sehingga tujuan dari produk ini dapat sesuai dengan target perusahaan, yaitu untuk meningkatkan penjualan.

b) Corporate Strategy

Strategi ini berkaitan dengan misi organisasi, sehingga sering disebut grand strategy yang meliputi bidang yang digeluti oleh suatu organisasi. Pada umunya perusahaan PT. 
HTI Bumi Persada Banyuasin pastinya harus memiliki misi / tujuan untuk meningkatkan penjualan produk yang diinginkan perusahaan.

Adapun faktor lain yang menjadi bahan pertimbangan perusahaan agar bauran produk dapat berjalan efektif dan efisien diantaranya adalah sebagai berikut :

1. Faktor produk

Produk yang ditawarkan oleh PT. HTI Bumi Persada Banyuasin adalah produk makanan / bakery seperti roti tawar,roti beragam rasa coklat, roti sobek dan lain-lain.

Mengingat perusahaan sejenis sangat banyak, tentu saja persaingan dibisnis ini sangat ketat, sehingga PT. HTI Bumi Persada Banyuasin harus pandai-pandai memilih produk yang tepat agar penjualan dapat meningkat.

2. Faktor konsumen

Kebanyakan

konsumennya orang awam tentu saja PT. HTI Bumi Persada Banyuasin dalam melakukan strategi produknya menggunakan bahasa yang mudah dipahami serta dengan bahasa yang menarik. Melalui strategi produk yang dilakukan perusahaan untuk menarik minat konsumen agar terus menerus melakukan pembelian terhadap produk yang diproduksi oleh perusahaan PT. HTI Bumi Persada Banyuasin.

\section{Strategi Penggunaan Merek Dagang}

Merek dagang terdiri dari nama, simbol, gambar atau kombinasi dari ketiganya yang dapat membedakan produk buatan perusahaan penghasilan produk buatan perusahaan tertentu dengan produk sejenis lainnya yang dijual di pasar.

Dalam memilih merek dagang PT. HTI Bumi Persada Banyuasin menggunakan merek dagang sesuai dengan standar nasional yang di tentukan oleh pemerintah, bahkan merek perusahaan PT. HTI Bumi Persada Banyuasin sudah terkenal di kota-kota besar maupun pelosok desa, merek dagang dipergunakan sesuai dengan luas daerah pemasaran yang dijangkau produk, merek dagang juga merupakan tanda untuk menunjukan kepada pembeli atau konsumen tentang perusahaan penghasilan produk yang bersangkutan. Bagi produsen merek dagang tidak berarti nama semata-mata merek dagang juga mengandung janji kepada pembeli bahwa produsen menjamin secara konsisten akan menyajikan, manfaat, kegunnan, atribut dan pernak pernik produk yang tetap memuaskan konsumennya.

\section{Strategi Tenaga Penjualan ( sales )}

Strategi tenaga penjualan mempunyai implikasi bagi strukturnya. Perusahaan yang menjual satu lini produk ke satu industri pengguna akhir dengan pelanggan di banyak lokasi akan menggunakan struktur teritorial.

Ujung tombak perusahaan untuk meningkatkan penjualan lainnya adalah tenaga penjual langsung ( sales ). Agar para sales dapat bekerja secara maksimal 
sesuai target perusahaan bahkan bila perlu melampauinya, PT. HTI Bumi Persada Banyuasin memberikan rangsangan target pencapaian penjualan, perusahaan tersebut memberikan insentif dan bonus serta sering juga di adakan pertemuan ( meeting ) untuk melakukan evaluasi kinerja para sales serta memberikan motivasi dengan cara mengadakan pelatihan-pelatihan sehingga mereka tidak hanya dijadikan sapi perah yang harus bekerja tanpa tujuan dan strategi yang memadai, yang pada akhirnya mereka merasa di hargai dalam bekerja oleh perusahaan tersebut serta mereka mendapatkan ilmu yang memadai untuk peningkatan kinerja mereka, dan pada akhirnya juga perusahaan dapat berkembang kearah yang lebih maju karena memiliki SDM yang memadai.

Pelatihan diberikan oleh perusahaan agar setiap usaha untuk meningkatkan kompetensi karyawan PT. HTI Bumi Persada Banyuasin dengan tujuan mengenal, mempelajari dan memberikan keterampilan yang ada agar bisa meningkatkan penjualan yang ada pada perusahaan.

\section{Strategi Pemilihan Media}

Dalam pemilihan media PT. HTI Bumi Persada Banyuasin memakai media massa seperti media elektronik ( televisi, radio ) bahkan media masa lokal seperti sriwijaya post, sumatra experss, dengan alasan agar konsumen lebih mengenal produk yang ditawarkan oleh perusahaan. Ada juga menggunakan media masa yang bertaraf nasional yang tambah memudahkan konsumen untuk memilih dan memesan produk yang ada.

Produk yang ditawarkan melalui media massa sangat penting karena menunjang untuk meningkatkan penjualan produk yang ditawarkan. Lalu media massa online pun ikut berperan penting dalam meningkatkan penjualan produk terbukti bisa dilihat dari volume penjualan yang ada pada bulan agustus penjualan meningkat. Terbukti karena strategi produk yang di terapkan perusahaan sudah mulai berjalan dengan baik.

\section{H. Pembahasan}

1) Strategi produk yang dilakukan PT. HTI Bumi Persada Banyuasin

Produk adalah segala sesuatu yang ditawarkan kepada suatu pasar untuk memenuhi keinginan atau kebutuhan . produk juga merupakan bagian dari usaha untuk meningkatkan penjualan sekaligus sebagai alat untuk mempengaruhi konsumen. Tujuan utama produk yaitu untuk menyediakan produk yang memuaskan pasar sasaran dan untuk mencapai tujuan organisasi perusahaan dan dapat mengembangkan, mengubah dan mempertahankan produk yang efektif.

Produk harus dilakukan dengan perencanaan yang tepat dan cermat, sebab produk yang dilakukan untuk dapat meningkatka penjualan perusahaan, oleh karena itu perusahaan harus bertindak cermat dalam setiap melakukan strategi produk agar tujuan produk, yaitu untuk meningkatkan penjualan dapat tercapai sesuai target yang di harapkan. 
Strategi produk yang dijalankan pada PT. HTI Bumi Persada Banyuasin memiliki tujuan yaitu untuk meningkatkan penjualan, dengan memperkenalkan produk kepada konsumen, sebagai produk yang berkualits baik dimata konsumen. Agar tujuan produk tersebut dapat tercapai dengan baik,efektif dan efisien. Perusahaan harus mempersiapkan, mengatur dan menetapkan strategi produk, dan sekaligus memperhatikan dan mengawasi efektivitas produk itu sendiri, dengan memiliki kerangka dan jadwal yang teratur dan terarah.

2) Produk yang digunakan PT. HTI Bumi Persada Banyuasin.

PT. HTI Bumi Persada Banyuasin dalam menjalankan bisnis perusahaannya menggunakan produk yang berkualitas tinggi, terbukti perusahaan ini banyak mendapatkan penghargaan yang berturut-turut oleh pemerintah kota dan pemerintah pusat. Karena higenisnya produk yang diproduksi oleh perusahaan PT. HTI Bumi Persada Banyuasin.

Adapun produk yang digunakan oleh PT. HTI Bumi Persada Banyuasin yaitu produk yang berupa produk makanan seperti produk sari roti beragam coklat, roti beragam isi selai, beserta roti tawar, dan lain-lain.

\section{Kesimpulan dan Saran}

1. Kesimpulan

Strategi produk yang dilakukan oleh PT. HTI Bumi Persada Banyuasin adalah dengan menggunakan strategi bauran produk, strategi pengguna merek dagang, strategi tenaga penjual ( sales ) serta strategi pemilihan media massa.
Strategi produk yang dilakukan oleh PT. HTI Bumi Persada Banyuasin sudah tepat hal ini dapat dilihat dari tabel penjualan yang meningkat pada bulan agustus sampai november dan dibanding pada bulan juli. Pada bulan agustus penjualan produknya mencapai Rp. 559.500 .000 dan dibulan november penjualannya meningkat menjadi Rp. 675.900.700.

\section{Saran}

Sebaiknya PT. HTI Bumi Persada Banyuasin memperbesar gedung, ataupun tempat produksi dalam menunjang produk yang ditawarkan kepada konsumen agar bisa lebih meningkatkan lagi penjualan produk yang ditawarkan.

Strategi produk yang dilakukan PT. HTI Bumi Persada Banyuasin sudah dapat meningatkan penjualan produknya terbukti pada saat angka penjualannya meningkat, maka dari itu sebaiknya perusahaan dapat mempertahankan penjualannya atau malah lebih meningkatkan lagi penjualan sesuai yang di harapkan.

\section{DAFTAR PUSTAKA}

Husen Umar. 2005. Metode Penelitian Aplikasi dalam Pemasaran. Penerbit PT Gramedia Pustaka Umum, Jakarta.

Kotler, Philip dan Keller, Kelvin Lane, 2009. Manajemen Pemasaran, Edisi 13 Jilid 1, Penerbit Erlangga, Jakarta.

Kotler, Philip dan keller, Kelvin lane, 2009. Manajemen Pemasaran, Edisi 13 Jilid 2 Penerbit Erlangga, Jakarta 
Mursid. 2006. Manajemen

Pemasaran. Jakarta, BUMI AKSARA

Sofyan Assauri.2002. Manajemen Pemasaran, Edisi Pertama,Cetakan ke Tujuh, Penerbut PT. Raja Grafindo Persada, Jakarta

Sugiyono. 2004. Metode Penelitian Bisnis, Penerbit Alfabeta, Bandung.
Sugiyono. 2010. Statistik Untuk Penelitian. Catatan ke-16. Alfabeta, Bandung

Suharsimi Arikunto. 2006. Prosedur Penelitian, Penerbit Rineka Cipta,Jakarta.

Swastha Basu dan Irawan. 2008. Manajemen Pemasaran, Moderen, Yogyakarta: Liberty

Swastha, Basu. 2009. Manajemen Penjualan. Edisi ke-3, Yogyakarta: BPFEYOGYAKARTA 